\title{
Assessment the thermal properties lightweight concrete produced by using local industrial waste materials
}

\author{
Osama AbdulAmeer \\ Building and Construction Engineering Department, University of Technology, Baghdad, Iraq
}

\begin{abstract}
In this research study of the thermal properties of light weight concrete produced from using two locally industrial wastes materials, to evaluate the thermal insulation, and some physical properties like strength of concrete (compressive and flexural tensile strength and variation of density of light weight concrete. Two types of wastes admixtures were used in this study, (chopped rubber, and wood sawdust) with $(5 \%, 10 \%, 15 \%$ and $20 \%)$ percent of each one. Thermal conductivity, compressive strength, flexural tensile strength and variation of density have been examined for each specimen at all percentages of admixtures, and compare with the reference concrete specimens. Experimental test results indicated that using these types of wastes as replacement of fine aggregate in concrete significantly affects the thermal conductivity, compressive strength, flexural tensile strength (rise or fall out), especially at (5\%) of adding materials, as well as utilization of additives in concrete to produce low density mixture with wood sawdust or as high density concrete when using rubber chopped in the concrete mixture.
\end{abstract}

\section{Introduction}

Thermal insulation and some of physical properties play an important role in constriction and designing of modern building, especially when considering wall properties such as weight and cost. Loss of heating from cement buildings occupies an important factor in air conditioning science. One of the main factors that affect cooling load in air conditioning space, is the thermal characteristics of building material. Increasing thermal insulation is the dominant factor in reducing heat that could be transfer of the building $[1,2]$. The best uses of waste materials depends on their use being economically competitive with the alternative natural material, these costs are primarily made up of handling, proceeding and transportations. For these mentioned reasons, many research works were endeavoured to make use of the enormous quantity of waste like, rubber tyres (chopped worn-out tyres), iron splinters (scrap), wood sawdust, ash rice husk and silica gel, to investigate the basic properties of concrete mixes with different admixtures, produce lightweight concrete, improve strength of concrete, and reduce costs of construction, as well as, reduce environmental pollution and preventing the accumulation of the raw materials. Industrial waste admixtures of concrete, generally have two main categories, organic wastes, and in-organic wastes (urban wastes) [3].

The objective of this work is to investigate some properties of concrete mixes with different additives, e.g., thermal conductivity, compressive strength, flexural strength, density (as light-weight concrete) and their influences on concrete behaviour. The additives included in this work are, rubber wastes (chopped wornout tyres), and sawdust which were added as replacement of fine aggregates to concrete with mixing ratio of concrete is $(1: 2: 4)$.

\section{Materials}

\subsection{Cement}

The ' Tasloga' ordinary Portland cement was used throughout this work. It is produced by factory in Sulymania. It is stored in air tight plastic containers to avoid exposures to different atmospheric conditions .The chemical \& physical properties are shown in Tables(1) \& (2) respectively. The tables conform to the limitations of Iraqi specification No. (5/1984) [4].

*Dr.osamaeedan@gmail.com

(C) The Authors, published by EDP Sciences. This is an open access article distributed under the terms of the Creative Commons Attribution License 4.0 (http://creativecommons.org/licenses/by/4.0/). 
Table 1. Chemical composition of the cement *

\begin{tabular}{|c|c|c|}
\hline Compounds & $\begin{array}{c}\text { \% by } \\
\text { weight }\end{array}$ & $\begin{array}{c}\text { Limits of } \\
\text { Iraqi spec. } \\
\text { No.5/1984 }\end{array}$ \\
\hline $\mathrm{Ca} \mathrm{O}$ & 61.5 & ----- \\
\hline $\mathrm{SiO}_{2}$ & 22.3 & ----- \\
\hline $\mathrm{Al}_{2} \mathrm{O}_{3}$ & 4.4 & ----- \\
\hline $\mathrm{Fe}_{2} \mathrm{O}_{3}$ & 2.74 & ---- \\
\hline $\mathrm{SO}_{3}(\%)$ & 2.65 & Less than 2.8 \\
\hline $\mathrm{Mg} \mathrm{O}(\%)$ & 2.5 & Less than 5.0 \\
\hline $\mathrm{L} . \mathrm{O} . \mathrm{I}(\%)$ & 1.9 & Less than 4.0 \\
\hline $\mathrm{C}_{3} \mathrm{~A}$ & 2.6 & Less than 3.5 \\
\hline
\end{tabular}

* These tests were made in (NCCLR).

Table 2. Physical properties of the cement

\begin{tabular}{|c|c|c|}
\hline physical properties & $\begin{array}{c}\text { Test } \\
\text { results }\end{array}$ & $\begin{array}{c}\text { Limits of Iraqi } \\
\text { spec. } \\
\text { No.5/1984 }\end{array}$ \\
\hline $\begin{array}{c}\text { Specific surface area blaine } \\
\text { Method } \mathrm{m}^{2} / \mathrm{kg}\end{array}$ & 375 & $>230$ \\
\hline $\begin{array}{c}\text { Setting time (Vicats } \\
\text { method) } \\
\text { Initial setting (min) } \\
\text { Final setting(min) }\end{array}$ & 196 & $<60$ \\
\hline soundness & $0.2 \%$ & $<600$ \\
\hline $\begin{array}{c}\text { Compressive strength of } \\
\text { Mortar (Map) } \\
\text { 3-days }\end{array}$ & 15.3 & \\
7-days & 27.5 & $>15$ \\
\hline
\end{tabular}

\subsection{Fine aggregate}

Natural sand from "El-Akhaider" was used for concrete mixes. All Tests of it indicate with conform to the limitations of No. (45/1984) specifications [5]. The (absorption, $\mathrm{SO}_{3}$ content, and the percentage of the materials finer than sieve No. 200sieve of the sand were $(1.19,0.22$., and 0.8$) \%$ respectively, and the specific gravity of that is 2.62 .The grain size distribution of the fine aggregate as shown in Table (3).

Table 3. Seive analysis of sand

\begin{tabular}{|c|c|c|}
\hline $\begin{array}{l}\text { Sieve size } \\
(\mathrm{mm})\end{array}$ & $\begin{array}{c}\text { Accumulated } \\
\text { percentage passing }\end{array}$ & $\begin{array}{c}\text { Limit of Iraqi speci. } \\
\text { No. 45/1984, Zone } \\
(3)\end{array}$ \\
\hline 4.75 & 100 & $90-100$ \\
\hline 2.36 & 95 & $85-100$ \\
\hline 1.18 & 90 & $75-100$ \\
\hline 0.6 & 75 & $60-79$ \\
\hline 0.3 & 38 & $12-40$ \\
\hline 0.015 & 7.5 & $0-10$ \\
\hline
\end{tabular}

Fineness modulus $=2.43$

\subsection{Coarse aggregate}

(5-19) $\mathrm{mm}$ natural crushed- gravel, was used in this study. Sieve analysis of it indicates that the conformance with the limitations of No. (45/1984) Iraqi specifications [5].

\subsection{Water}

In mixing and curing, potable water was used.

\subsection{Admixtures}

Industrial wastes (saw dust and rubber chopped) were used in this work as admixture. The chemical analyses of these admixtures are shown in Table (4 and 5).

Table 4. Chemical properties of Tires (rubber) cutting *

\begin{tabular}{|c|c|}
\hline composition & content $\%$ \\
\hline Rubber hydrocarbon & 48 \\
\hline Carbon black & 31 \\
\hline Acetone extract & 15 \\
\hline Ash & 2 \\
\hline Residue chemical balance & 4 \\
\hline
\end{tabular}

* Testing was made at Babylon Tyres Factory.

Table 5. Chemical analysis of wood saw dust*

\begin{tabular}{|c|c|}
\hline Oxide composition & Content \% \\
\hline $\mathrm{SiO}_{2}$ & 86.2 \\
\hline $\mathrm{CaSO}_{3}$ & 2.8 \\
\hline $\mathrm{Al}_{2} \mathrm{O}_{3}$ & 4.5 \\
\hline $\mathrm{Mg} \mathrm{O}$ & 2.5 \\
\hline $\mathrm{SO}_{3}$ & 2.2 \\
\hline Loss on ignition & 1.8 \\
\hline
\end{tabular}

*Analysis was made at X-Ray Diffract -Meter, type XRD6000

\section{Mix proportion}

The mixing process was performed in pan type mixer of $(0.1) \mathrm{m}^{3}$ capacity. The aggregate and saw wood dust were used in a saturated surface dry condition. The dry materials were well mixed for about 1.5 minutes to satisfy uniform mix, then the amount of required tap water was added and the mix elements were mixed for another 1.5 minutes.

All molds used, were cleaned, and the surface of it was oiled and filled with concrete in layers and compaction was made by vibrating table for a period of 20 seconds/layer. Care was taken to avoid concrete segregation. Then the top faces of the molds were troweled. After casting, the specimens were covered with polyethylene sheets to avoid cracks associated with the plastic shrinkage and maintained in moist cabinet at a temperature of $23 \pm 1^{\circ} \mathrm{C}$ and the relative humidity of about $90 \%$. The specimens were then remolded after 24 hours from casting, then the specimens were placed in tap water for 28 days after this period the specimens were removed from water and left inside the Laboratory for 3 days to allow for drying. 


\section{Experimental tests}

\subsection{Thermal conductivity}

Thermal conductivity measure of the quantity of the heat that flows through a material per unit time. Thermal conductivity of most materials found to change with the percentage of impurities or admixtures. From the Furriers steady -state heat condition equation (thermal conductivity) is determined as follows:

$K=(Q)(\Delta X) /(A)(\Delta T)$

\section{Where:}

$K$ : Thermal Conductivity $\left(w / m .{ }^{\circ} \mathrm{C}\right)$.

$Q$ : The Heat Transfer rate $(\mathrm{kj})$.

A: Area $\left(\mathrm{m}^{2}\right)$.

T: Temperature $\left({ }^{\circ} \mathrm{C}\right)$.

The Thermal Conductivity was run in the laboratories of Material Engineering Department, University of Technology. The samples were prepared to determine the thermal conductivity of concrete and the test apparatus -Less disc apparatus - type (Griffin and George) as shown in Plates (1and 2) [6].

\subsection{Physical properties tests}

Experimental work have been carried out according to Iraqi specification Code 1989(CBRI, 1989) [7], and B.S. (1881-1983) [8], for compressive strength tests and density, and according to ASTM (C192-07) [9], for flexural tensile strength tests. The admixtures were used with different weight percentages from cement content $(5 \%, 10 \%, 15 \%$, and $20 \%)$ for rubber particles and wood saw dust, the mixing ratios of reference concrete are 1:2:4, with water cement ratio $(\mathrm{w} / \mathrm{c})$ of $(0.5)$. Average of three specimens was taken for each ratio.

\section{Discussion of results}

\subsection{Effect of adding wastes on concrete strength and density}

The tests results provide the behavior for concrete for each type of admixtures. This research revealed that the compressive strength of concrete (in 28 days ) increased with adding (5\%) of different types of admixtures as shown in Table (6), and Fig.(1)
Table 6. The compressive strength results of the concrete samples with different additives types

\begin{tabular}{|c|c|c|}
\hline $\begin{array}{c}\text { Admixtures } \\
\% \\
\text { (by wt. of } \\
\text { cement) }\end{array}$ & $\begin{array}{c}\text { Compressive strength } \\
\text { of concrete in } \\
\text { (28 days) containing } \\
\text { Rubber cutting } \\
\mathrm{N} / \mathrm{mm}^{2}\end{array}$ & $\begin{array}{c}\text { Compressive strength } \\
\text { of concrete in }(28 \\
\text { days) containing } \\
\text { wood saw dust } \\
\mathrm{N} / \mathrm{mm}^{2}\end{array}$ \\
\hline 0 & 25.53 & 25.51 \\
\hline 5 & 28.76 & 28.3 \\
\hline 10 & 23.36 & 21.4 \\
\hline 15 & 16.88 & 17.3 \\
\hline 20 & 15.52 & 24.08 \\
\hline
\end{tabular}

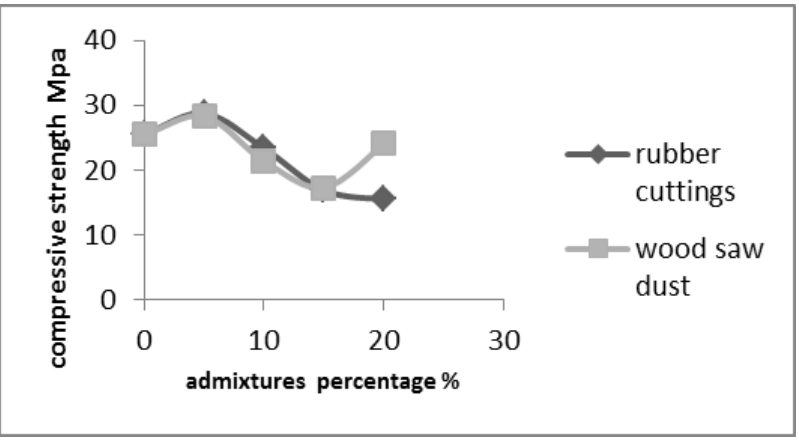

Fig. 1. Compressive strength of with different types and percentages of admixtures.

Concrete modified by rubber chopped with $5 \%$ have been noticed to be able to increase the compression strength as shown in Fig.(1). This increase is about (8.4) with respect to reference concrete, while decrease for other admixture percentages. This could be attributed to the inclusion of cutting inside existing voids and pores through mixture, which behaves as bond material. While, when increasing the addition ratio (more than 5\%), the rubber will act as weakness regions. Wood dust increases the concrete compressive strength of about (13\%), by using (5\%) addition percentage, compared to reference concrete as shown in Fig.(1) .This can be attributed to the high content of $\left(\mathrm{SiO}_{2}\right)$ in saw dust , and the texture of this material, which reflect in concrete mixture .The concrete density with additives show significant decreasing in comparison with normal concrete. Table (7) shows that the rubber cutting gives density less than wood saw dust, also see Fig.(2). 
Table 7. Dry density of concrete with different percentages of wastes.

\begin{tabular}{|c|c|c|}
\hline $\begin{array}{c}\text { Admixtures } \\
\% \\
\text { (by wt. of } \\
\text { cement) }\end{array}$ & $\begin{array}{l}\text { Dry density of } \\
\text { concrete } \\
\text { containing of } \\
\text { rubber chopped } \\
\quad\left(\mathrm{kg} / \mathrm{m}^{3}\right)\end{array}$ & $\begin{array}{l}\text { Dry density } \\
\text { of concrete } \\
\text { containing of } \\
\text { wood saw } \\
\text { dust }\left(\mathrm{kg} / \mathrm{m}^{3}\right)\end{array}$ \\
\hline 0 & 2400 & 2400 \\
\hline 5 & 2403 & 2442 \\
\hline 10 & 2369 & 2436 \\
\hline 15 & 2285 & 2398 \\
\hline 20 & 2177 & 2374 \\
\hline
\end{tabular}

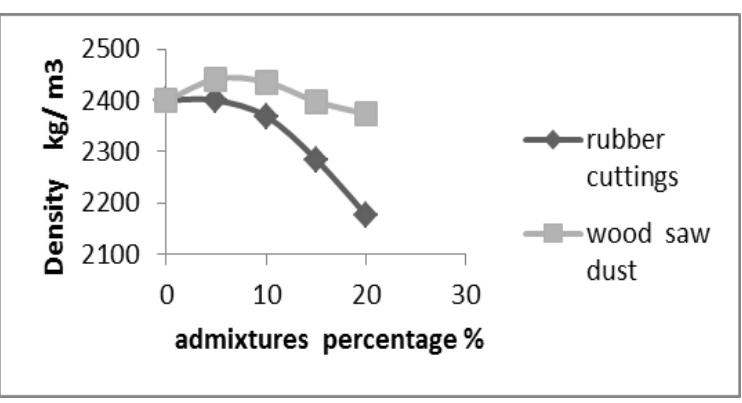

Fig. 2. Dry density of with different types and percentages of admixtures.

Table (8) and Figure (3), shows the behavior flexural strength of concrete (with size of specimens used $100 * 100 * 400 \mathrm{~mm}$ ) modified by addition of the different percentage of additives (rubber cutting and saw wood dust). They shows that the flexural strength is decreased with increasing of rubber cuttings while, it is increased with increasing saw wood dust. The maximum flexural strength was provided by adding (10\%) of saw dust.

Table 8. Flexural strength of concrete

\begin{tabular}{|c|c|c|}
\hline $\begin{array}{c}\text { Admixtures } \\
\%\end{array}$ (by wt. of cement) & $\begin{array}{c}\text { Flexural strength } \\
\text { of concrete } \\
\text { containing rubber } \\
\text { cuttings } \\
\left(\mathrm{N} / \mathrm{mm}^{2}\right)\end{array}$ & $\begin{array}{c}\text { Flexural tensile } \\
\text { strength of } \\
\text { concrete containing } \\
\text { wood saw dust } \\
\left(\mathrm{N} / \mathrm{mm}^{2}\right)\end{array}$ \\
\hline 0 & 5.6 & 5.6 \\
\hline 5 & 5.12 & 5.65 \\
\hline 10 & 3.77 & 6.15 \\
\hline 15 & 2.88 & 5.92 \\
\hline 20 & 1.83 & 5.80 \\
\hline
\end{tabular}

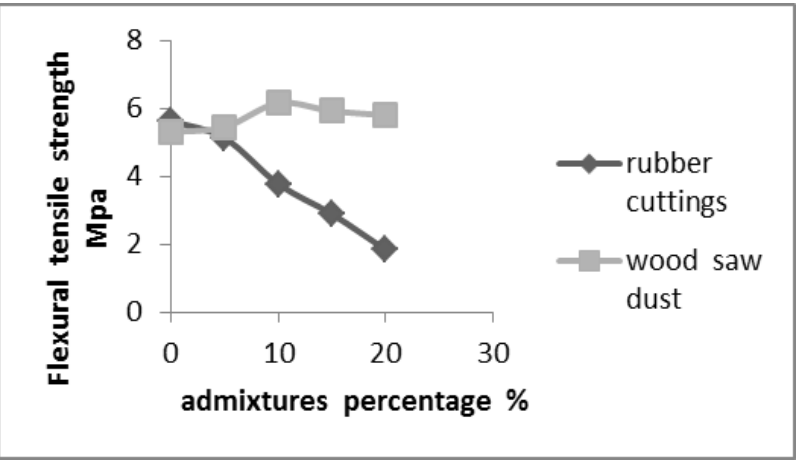

Fig. 3. Flexural strength of with different types and percentages of admixtures

\subsection{Effect of additives on thermal conductivity of concrete}

Table (9) shows the thermal conductivity of rubber and wood saw dust and, Fig.(4) shows the relationship between thermal conductivity and admixtures percentages. It is clear that the increase of additives leads to decrease in thermal conductivity value. Fig.(4) shows the effect of wood ratio on the thermal conductivity of concrete .It is clear that the increase in wood ratio leads to a decrease in thermal insulation, this is due to the presence of voids within the concrete matrix which affects thermal conductivity of the produced material.

Table 9. Thermal conductivity of concrete

\begin{tabular}{|c|c|c|}
\hline $\begin{array}{c}\text { Admixtures } \\
\% \\
\text { (by wt. of } \\
\text { cement) }\end{array}$ & $\begin{array}{c}\text { Thermal } \\
\text { conductivity of } \\
\text { concrete containing } \\
\text { rubber cuttings } \\
\text { (w/m.k) }\end{array}$ & $\begin{array}{c}\text { Thermal conductivity } \\
\text { of concrete } \\
\text { containing wood saw } \\
\text { dust (w/m.k) }\end{array}$ \\
\hline 0 & 0.704 & 0.704 \\
\hline 5 & 0.638 & 0.539 \\
\hline 10 & 0.550 & 0.441 \\
\hline 15 & 0.480 & 0.322 \\
\hline 20 & 0.420 & 0.218 \\
\hline
\end{tabular}




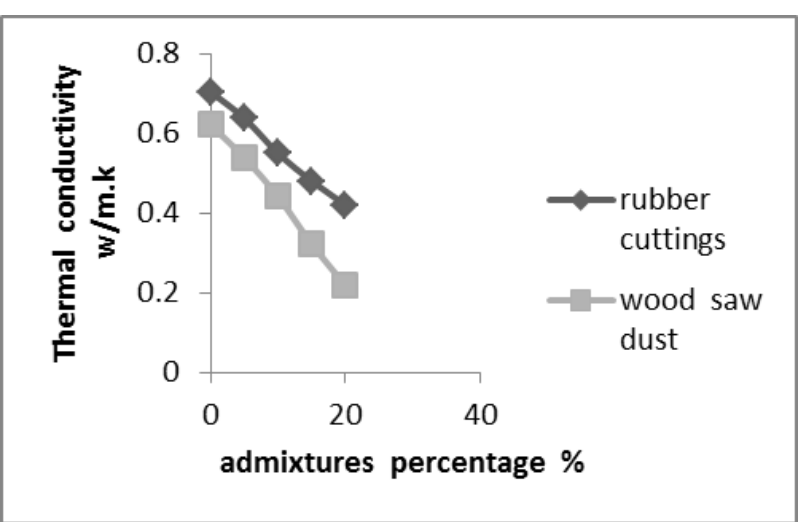

Fig. 4. Thermal conductivity of concrete

\section{Conclusions}

This study has been carried out to investigate the behavior of concrete addition of organic and nonorganic wastes mixtures .The study concludes the following points

1. Adding 5\% chopped rubber or saw dust wood gives increase in compressive strength of concrete by $11.23 \%$, and $9.78 \%$,respectively.

2. Flexural strength of mixed concrete with rubber cutting decreases considerably by increasing the rubber additives, while wood saw dust increased flexural strength.

3. The thermal conductivity of concrete mixes decreases, with addition of the rubber cutting or saw dust wood.

4. The use of waste industrial materials as a replacement of aggregate (which represents the main salt sources) reduces the salt concentrations in the concrete mixture; this may be lead to improvement the durability of concrete.

\section{Appendix}

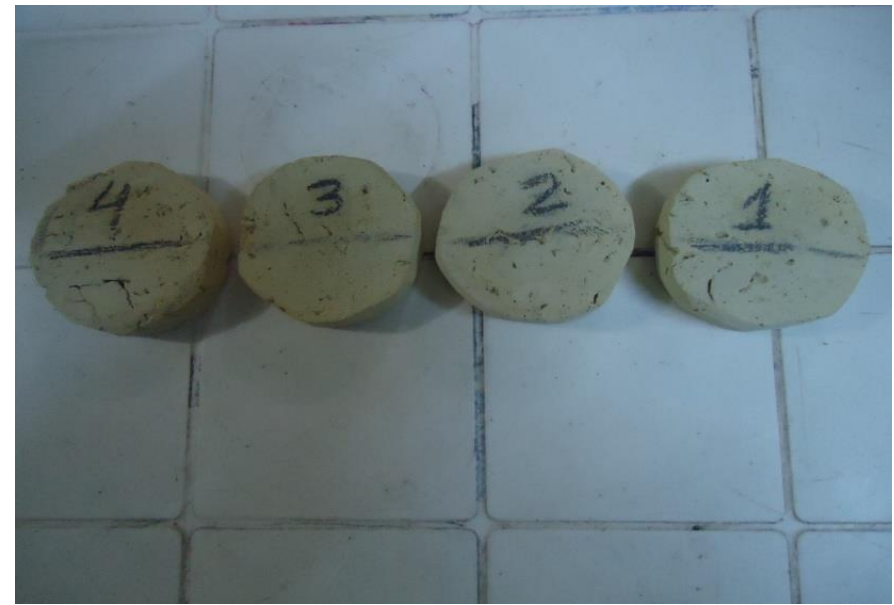

Plate 1. The concrete samples

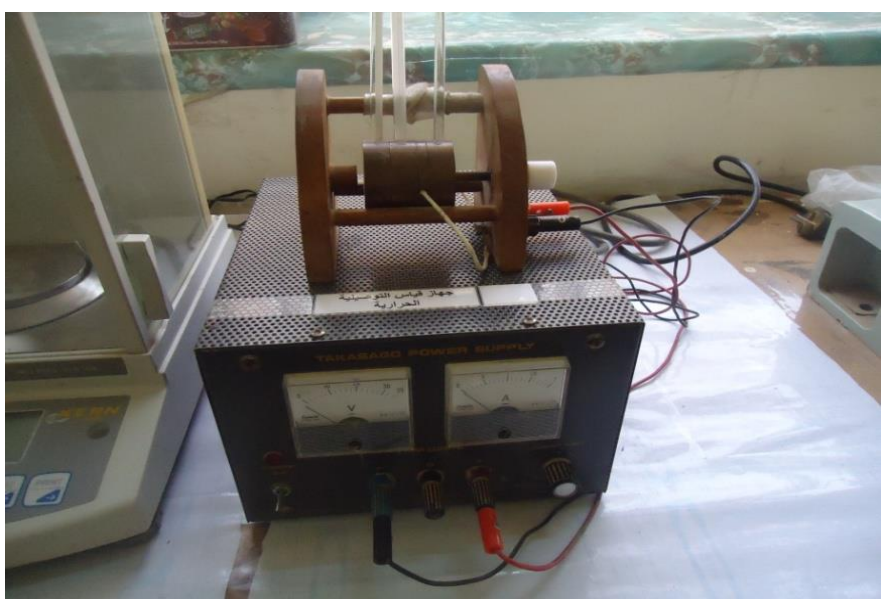

Plate 1. The concrete samples

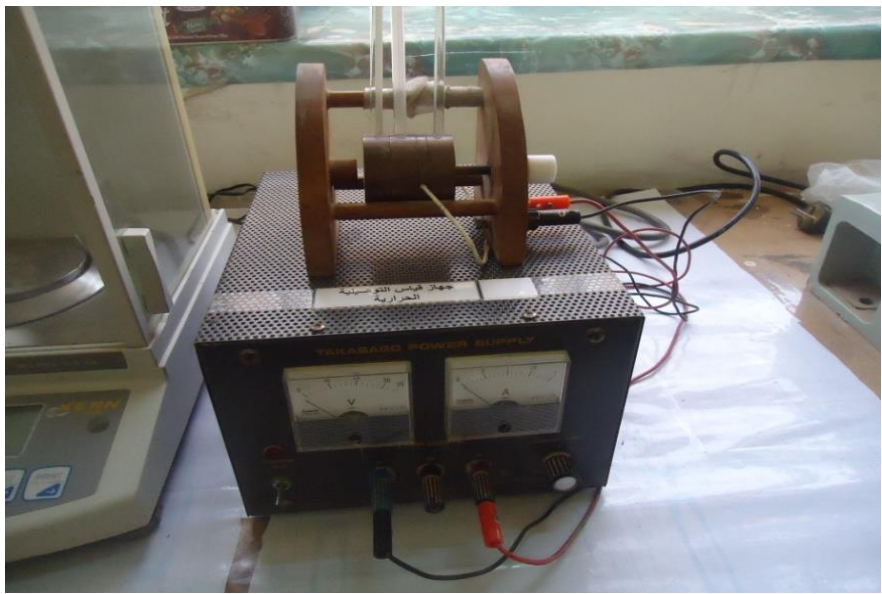

Plate 2. Lees Disc apparatus

\section{References}

1. P. Turgut, and B. Yesilata, ",(Energy \& Building ,pp ,679-688, 2008)

2. M.S. Solemez, (Building and env. ,pp1-5, 34 1991).

3. ACI committee 213, guide for structural light weight aggregate concrete, ACI manual of concrete practice ,part-1, materials and general properties of concrete (1999).

4. I.Q. Iraqi Specifications No. 5, "Portland Cement”, Baghdad, (1984).

5. I.Q. Specifications No. 45, "Natural Sources for Gravel that is Used in Concrete and Construction", Baghdad, 1984. 
6. CBRI, Central Building Research Institute coconut pith cement concrete for thermal insulation, Building Materials, No.9, Rookie, India, (1993).

7. I.Q. Specification code, Ministry of planning, Iraq, (1989).

8. B.S. British standard institute, Method of making and curing test specimens, BS 1881, part-3, London, (1983).

9. ASTM, C192-2007, Standard practice for making and curing test specimens in the Laboratory ,Annual book of ASTM standard ,Philadelphia, vol. 04 , (2007). 